\title{
22. SEDIMENTOLOGY AND PETROLOGY OF MISSISSIPPI FAN DEPOSITIONAL ENVIRONMENTS, DEEP SEA DRILLING PROJECT LEG 96 ${ }^{1}$
}

\author{
Paul A. Thayer, Amoco Production Company \\ Harry H. Roberts, Louisiana State University \\ Arnold H. Bouma, Gulf Research and Development Company \\ and \\ James M. Coleman, Louisiana State University ${ }^{2}$
}

\begin{abstract}
Pleistocene sediments were cored at nine middle and lower Mississippi Fan sites, in water depths from 2500 to $3300 \mathrm{~m}$. Radiography, thin section, scanning electron microscope, and X-ray diffraction studies provide data to describe the fan's major depositional environments.

Sands and minor gravels are concentrated in middle and lower fan channel fills, and in lower fan channel-mouth deposits. Silts and clays occur in overbank deposits, passive channel fills, and interbeds associated with coarser facies. Graded bedding and lamination, both of varying thickness, are the dominant sedimentary structures in all environments.

Granule and pebble gravels are composed of well-rounded chert and polycrystalline quartz, with minor metamorphic and igneous rock fragments. Moderately to well sorted sands are mainly fine and very fine feldspathic litharenite, sublitharenite, and subarkose. Sands commonly have thin-section porosities between 20 and $35 \%$; woody organic contents range from 0.7 to $7.9 \%$ total organic carbon.

Authigenic minerals occur in sands and muds, but are most common in fine-grained silts and clays. Smectite, dolomite, calcite, pyrite, and gypsum are the main authigenic phases.

At this stage in their depositional history, the sands are relatively clean, have high porosities, show only minor porereducing diagenetic effects, and thus have excellent hydrocarbon reservoir potential.
\end{abstract}

\section{INTRODUCTION}

Cores from nine Deep Sea Drilling Project (DSDP) Leg 96 Mississippi Fan drill sites (Fig. 1) provided samples from which the sedimentologic and petrographic characteristics of the fan's major depositional environments can be described. The cores were taken in water depths of 2500 to $3300 \mathrm{~m}$, and are from the youngest fan lobe, which is late Wisconsin in age (see introductory chapter, this volume). Middle fan samples come from channelfill sequences (Sites 621 and 622), overbank deposits (Sites 617 and 620), and slumped marginal-fan (Site 616) sediments. Lower fan samples are from channel-fill (Site 623) and overbank deposits (Site 624), as well as channel-mouth depositional lobes (Sites 614 and 615).

This chapter summarizes initial results of our sedimentologic and petrographic studies of Mississippi Fan cores. Our objectives are to document combinations of primary sedimentary structures, textures, compositions, diagenetic features, and porosity characteristics within the vertical sedimentary sequences of the fan's major depositional environments. Detailed core descriptions can be found in the site chapters (this volume).

\footnotetext{
${ }^{1}$ Bouma, A. H., Coleman, J. M., Meyer, A. W., et al., Init. Repts. DSDP, 96: Washington (U.S. Govt. Printing Office).

2 Addresses: (Thayer, present address) Mobil Oil Exploration and Producing Southeast Inc., 1250 Poydras Bldg., New Orleans, LA 70113; (Roberts, Coleman) Coastal Studies Institute, Louisiana State University, Baton Rouge, LA 70803; (Bouma, present address) Cherron Oil Field Research Company, P.O. Box 36506, Houston, TX 77236.
}

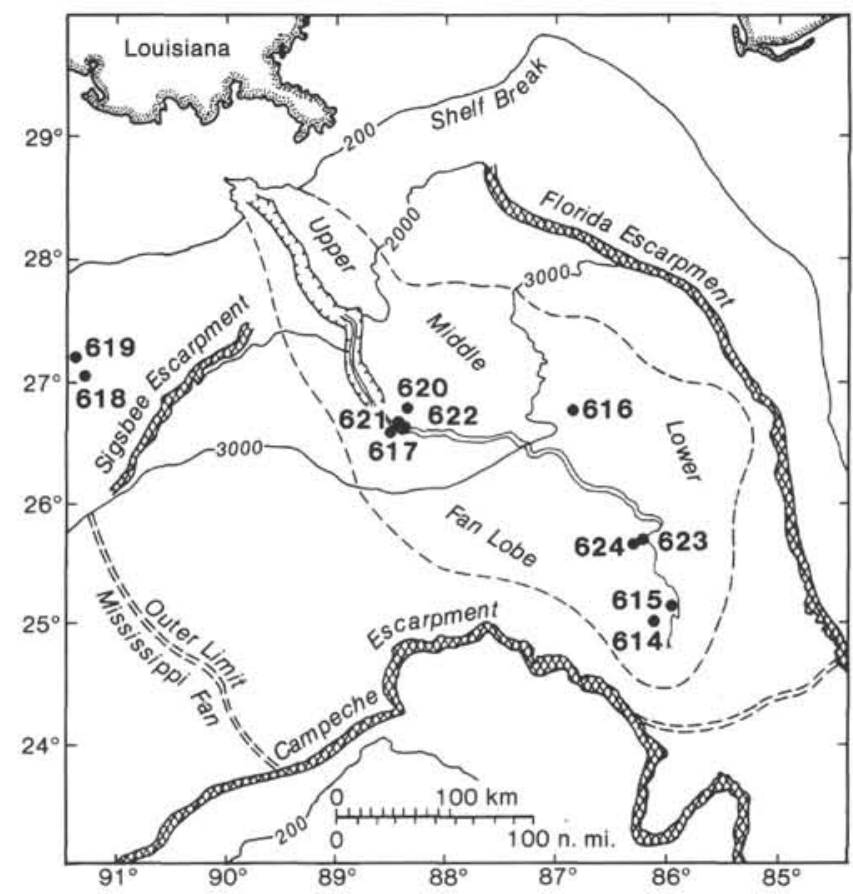

Figure 1. Location map of DSDP Leg 96 drill sites.

\section{METHODS}

A variety of analytical techniques were used. Sediment slabs (6-mm thick, $7.5-\mathrm{cm}$ wide, and $30-\mathrm{cm}$ long) were sampled on board ship, sealed in Plexiglas frames, and transported to the laboratory for X-ray radi- 
ography. Slab radiography proved to be exceptionally valuable to describe macroscopic sedimentary structures and diagenetic inclusions, as well as to determine locations for detailed subsampling and analysis. A total of 108 sediment slabs were radiographed (Coleman, Bouma, et al., this volume). From these slabs and other samples collected on board ship, representative subsamples were selected for thin section, scanning electron microscope, X-ray diffraction, and source rock analyses.

Two hundred and three thin sections were prepared from undisturbed, air-dried samples. Most samples were impregnated with bluedyed epoxy under vacuum in a chamber pressured with nitrogen at $2000 \mathrm{psi}$. Volume percent composition of sand and silt samples was determined by point-counting 108 thin sections using 300 counts per slide, and a point distance slightly larger than maximum grain diameter. Staining for potassium feldspar and calcite facilitated identification of these minerals. Mean size and sorting of sands and silts was determined by measuring long diameters of 100 terrigenous grains in thin section and converting to equivalent sieve values using formulas published by Harrell and Eriksson (1979). All thin section samples containing primarily sand and silt were examined with a stereo binocular microscope for roundness and sphericity.

Scanning electron microscopy (SEM) coupled with energy dispersive X-ray analysis (EDX) was used to study texture, fabric, and diagenetic mineralogy of 46 sand and mud (silt and clay) samples (Wilson and Pittman, 1977).

Bulk clay mineralogy of 112 air-dried muds was done by X-ray diffractometry (XRD) utilizing standard techniques (Roberts, 1985). Semiquantitative estimates of percent kaolinite, illite, and smectite were determined by peak-area analysis. Clay mineralogy of the $<2-\mu \mathrm{m}$ fraction of 26 sand samples was analyzed by a commercial laboratory.

Total organic carbon (TOC) of 13 sands was determined by pulverizing the samples, treating them with warm hydrochloric acid to remove carbonate carbon, and analyzing the residue for carbon with a Leco carbon analyzer. The hydrocarbon-generating capability of the sands was assessed by Rock-Eval pyrolysis (Hunt, 1979).

\section{DEPOSITIONAL ENVIRONMENTS}

Three Mississippi Fan depositional regimes were cored during DSDP Leg 96: middle fan channel-overbank complex, lower fan channel-overbank complex, and slumpmarginal fan slope (Fig. 1). Cores from each of these three major areas have textures, sedimentary structures, and diagenetic features that are indicative of the depositional environments encountered.

Four sites were cored on the middle fan channel and overbank complex. Sites 621 and 622 show a fining-upward channel fill sequence beginning with a basal, clastsupported, pebbly gravel. The gravel grades upward into massive quartzose sands (Fig. 2A) containing chert granules, mica, and woody organic debris. Although core recovery was poor, gamma-ray logs suggest the presence of up to $100 \mathrm{~m}$ of sand interbedded with thin silts and clays at the bottom of each of these channel sites (Coleman, Constans et al., this volume). The sands contain few sedimentary structures, possibly the result of liquefaction during coring operations. Small-scale cross-laminations and graded units are the dominant structures (Fig. 2B). Clay clasts are sometimes present. Transported woody fragments ("coffee grounds") occur as thin bedded units within the sands and silts (Fig. 2B). Although the muds display a few burrowed horizons, there is a general lack of bioturbation features in cores from both sites. The finer grained parts of the channel fill are composed of faintly (Fig. 2C) to well laminated clays and silty clays organized into thin graded units beginning with a sharp-based silt or silty clay. In the upper fine-grained "passive" channel fill, thin graded laminations contain- ing nodular masses of authigenic pyrite and carbonate are the most common sedimentary structures (Fig. 2C). These nodular masses are typical of the finer grained clay-rich facies.

Middle fan overbank deposits (Sites 617 and 620) consist dominantly of silt and clay, and contrast with channel fill sediments by containing only minor amounts of very fine sand. Cores from Site 617, the least disturbed of the two, consist mainly of graded silts and clays organized into thinly bedded units (Fig. 3A). Stranded ripples, small load features, and clay clasts are common structures in very fine sand units. Mud-rich units display very thin laminations, usually grading from fine silts or coarse clays to extremely fine clays (Fig. 3A). Although bioturbation features are present, they are not common. One of the dominant characteristics of middle-fan overbank sediments is the frequent occurrence of penecontemporaneous deformational structures that range in size from several meters to small-scale convolutions. The deformed bedding probably results from compaction and dewatering associated with high clay content and rapid sedimentation rates.

Lower fan channel-overbank deposits (Sites 623 and 624) consist of numerous silt and thin sand units, organized generally into fining-upward sequences. The sands are always sharp based, and may be massive (Fig. 3B) or have small-scale cross-laminations; they sometimes contain large clay clasts. Silts are usually graded and arranged into numerous thin cycles, with coarse silt to fine sand at the base and clay at the top (Fig. 3C). These small graded units vary from a few millimeters to several centimeters thick. Silt units often display microcross-laminations. Silts also occur as lenticular masses and stranded ripples with micro-laminated structure. Contorted bedding is a common feature in silt-rich units of Site 624 (Fig. 3C). Bioturbation and secondary diagenetic structures are lacking. However, transported woody organic debris is common in coarser sand units.

Channel-mouth depositional lobes of the lower fan (Sites 614 and 615) are composed dominantly of silts and massive sands (Fig. 4A, 4B). The top and bottom contacts of the sands are sharp and sometimes scoured at the base. Except for clay clasts 1 to $5 \mathrm{~cm}$ long (Fig. 4A) and well-defined horizons of woody organic fragments, these coarse units are poorly sorted and display little internal structure. Interbedded clay and silty clay units generally are graded and occur in repetitive cycles a few millimeters to tens of centimeters thick (Fig. 4B). Minor small-scale burrow structures are found in finer grained parts of the sequence. One of the more common attributes of the graded units in these cores, as well as many of those in the overbank deposits, is the occurrence of a thin concentration of microfauna, mostly planktonic foraminifers, at the tops of the thin graded units. The concentration of foraminifers suggests a break in sedimentation after each thin graded unit is deposited.

Site 616 was drilled on the margin of a massive fan slump. The upper $96 \mathrm{~m}$ of core consists of sediment that is presently interpreted as a displaced sequence (Walker and Massingill, 1970). The sequence consists of clay and 
A

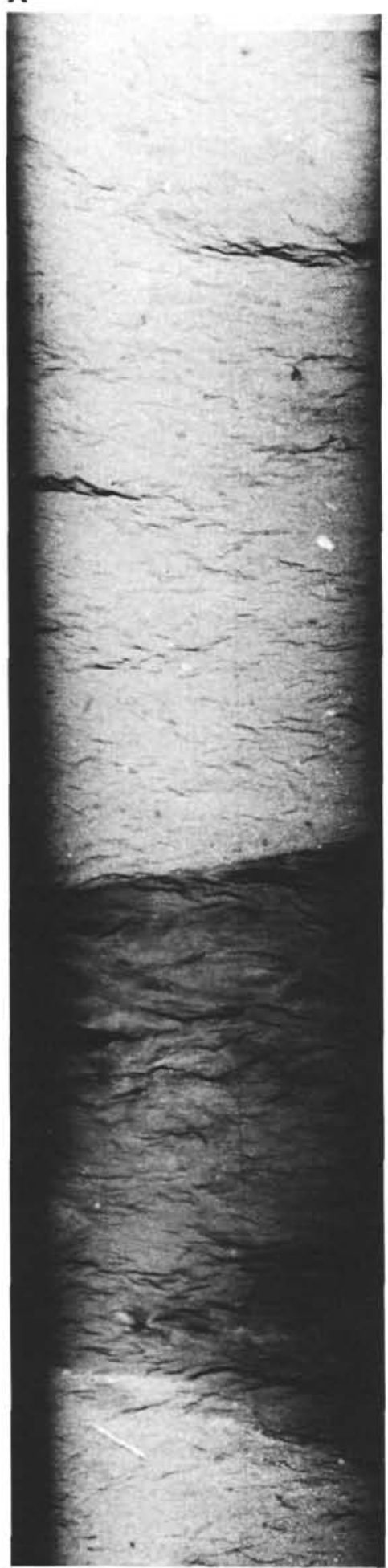

B

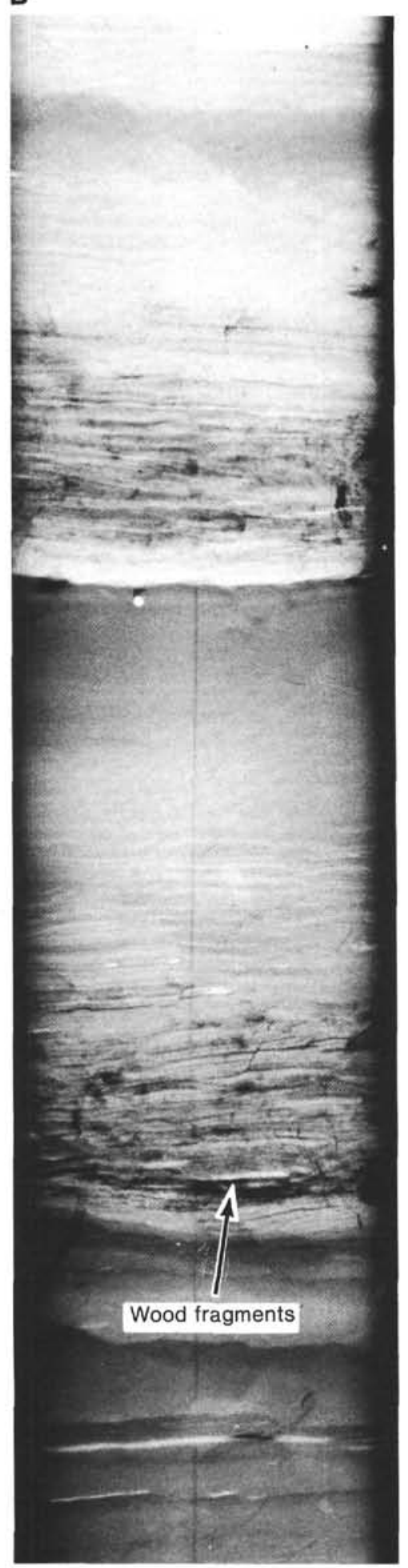

5
C

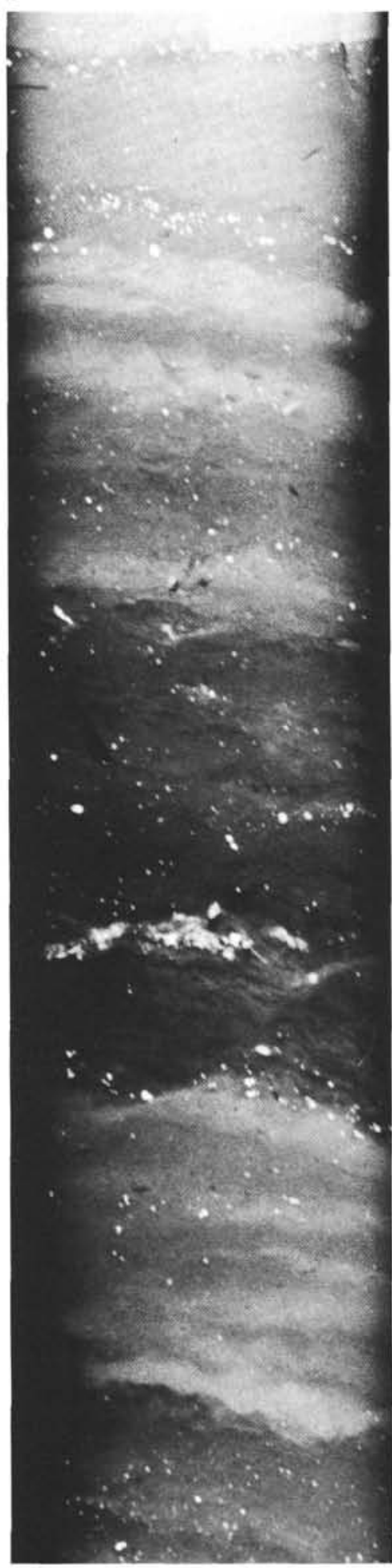

$\mathrm{cm}$

Figure 2. X-ray radiographs of channel fill deposits. High-density areas (sands and most diagenetic features) are represented by light tones. The scale (shown in B) is the same for each radiograph. A. Massive, poorly sorted quartzose sands containing chert granules, mica, shell debris, and woody organic fragments. Note sharp basal contact and lack of internal structures. Sample $621-21-2,40-70 \mathrm{~cm}$ (133.8 m sub-bottom). B. Cyclic, graded packets containing small-scale cross-laminations in basal portions. Sample 622-11-3, 95-125 cm (103 m sub-bottom). C. Poorly defined graded clay and silty clay unit of the upper passive channel fill. A variety of high density diagenetic masses (white areas) include pyrite framboids and framboid clusters, and calcite- and pyrite-filled microfossil tests. Sample $622-2-3,96-126 \mathrm{~cm}$ (7.5 m sub-bottom). 
A

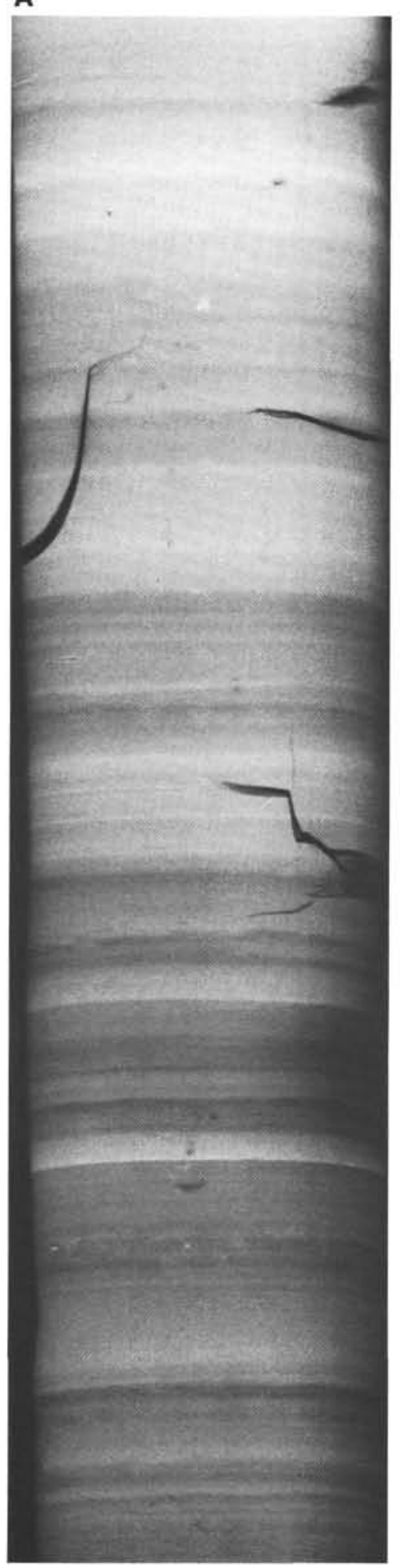

B

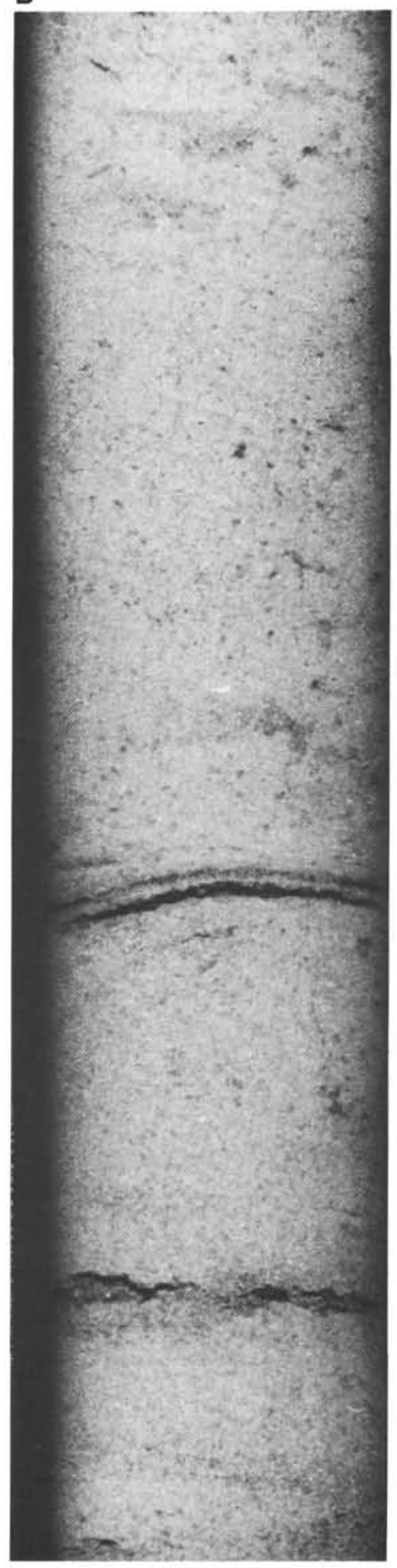

5

0
C
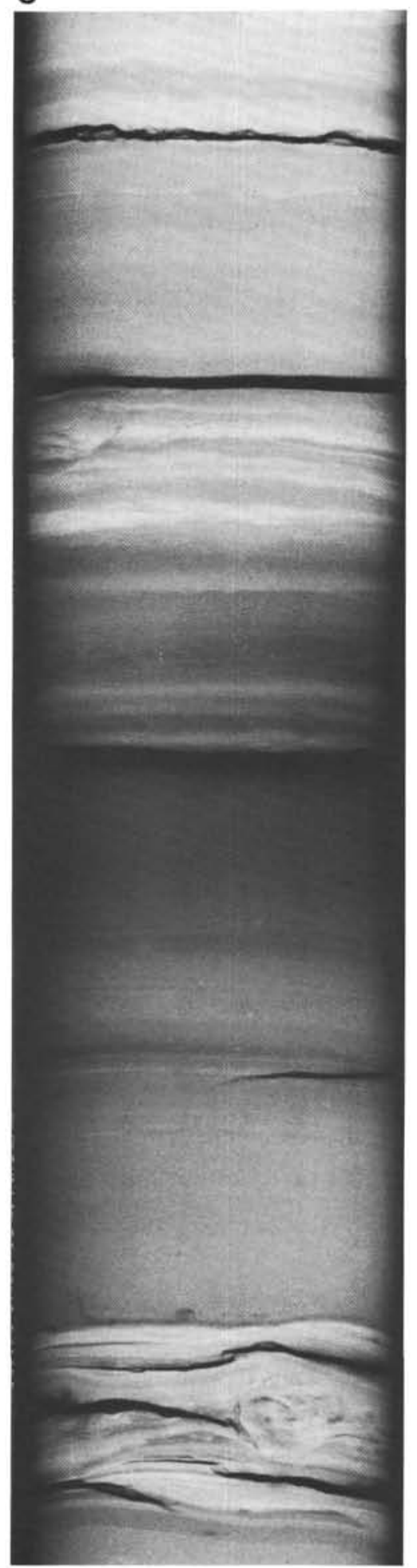

$\mathrm{cm}$

Figure 3. X-ray radiographs of middle fan overbank deposits and lower fan channel-overbank sediments. High-density areas (sands and silts) are represented by light tones. The scale (shown in B) is the same for each radiograph. A. Silts and silty clays of middle fan overbank deposits organized into thin units with delicately graded laminations. Sample $617-2-3,106-136 \mathrm{~cm}$ (12.2 m sub-bottom). B. Massive sands of the lower fan channel-overbank complex. Note cracks along bedding planes between woody organic debris (black layers) and sands (light areas). Sample 623-8-2, 21-51 cm (66.1 m sub-bottom). C. Graded packets of structured and contorted silts to clays of the lower fan channel-overbank complex. Sample 624-6-4, 0-30 cm (49.8 m subbottom). 
A

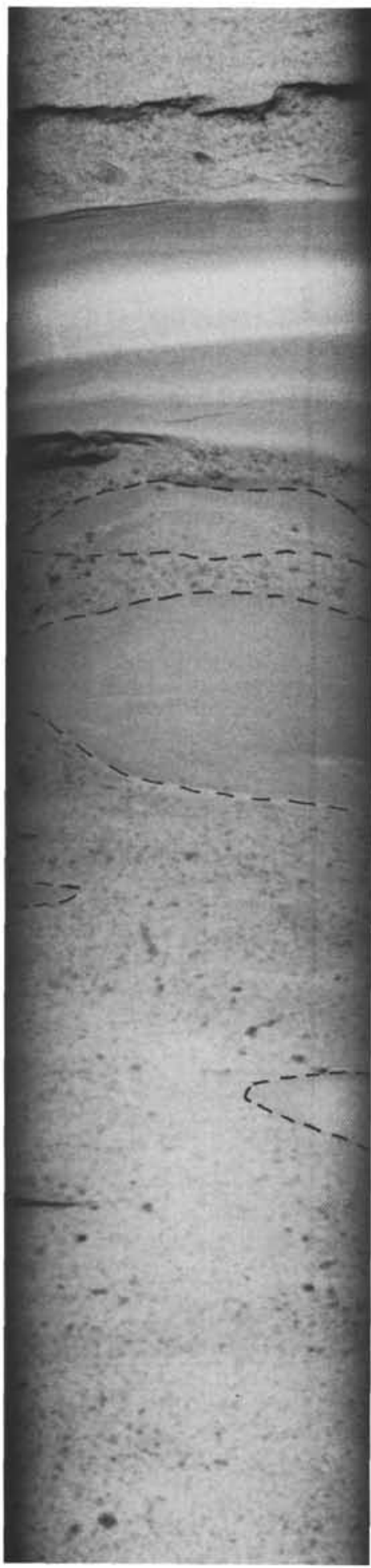

B

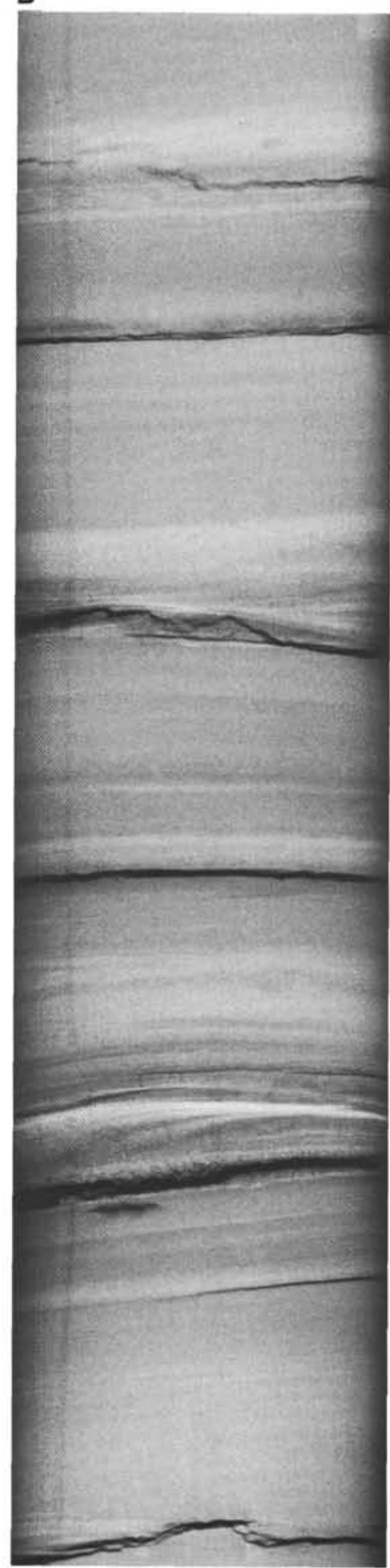

0
C

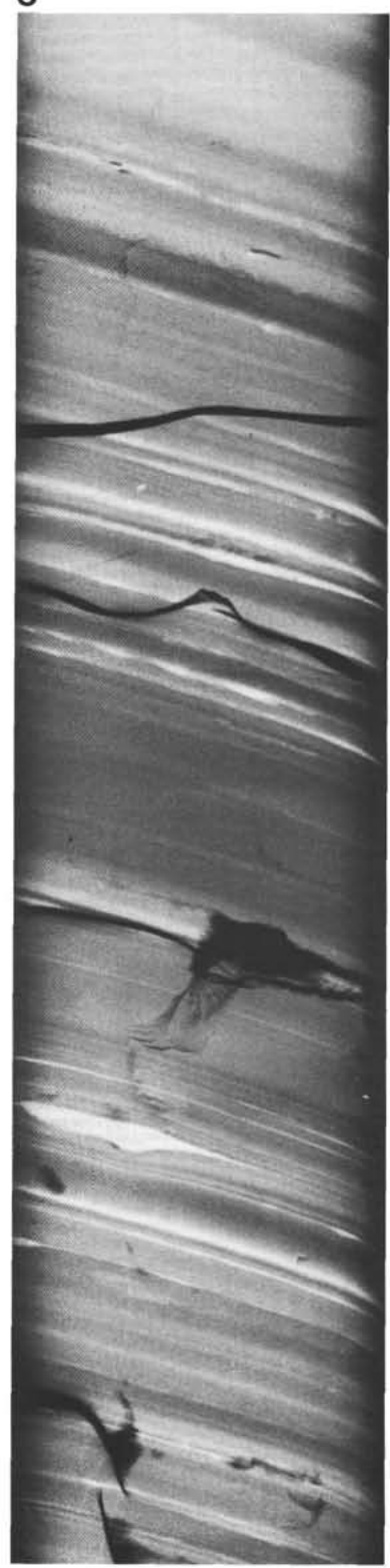

$\mathrm{cm}$

$\mathrm{m}$

Figure 4. X-ray radiographs of lower fan channel mouth lobes and marginal fan slump. High density areas (sands and silts) are represented by light tones. The scale (shown in B) is the same for each radiograph. A. Massive sands containing scattered woody organic debris (dark spots) and large clay clasts. Sample 615-22-2, 56-85 cm (192.9 m sub-bottom). B. Interbedded clay and silty clay units with one packet containing fine sand. Core is separated along sand and structured silts. Sample 614$8-2,59-89 \mathrm{~cm}$ ( $100.7 \mathrm{~m}$ sub-bottom). C. Inclined bedding of the marginal fan slump. The dark lines represent cracks created during the core-cutting process. Sample $616-2-3,72-102 \mathrm{~cm}$ ( $9.9 \mathrm{~m}$ sub-bottom). 
thin silt stringers, and is characterized by steeply inclined bedding (Fig. 4C) and contorted structures, with less common fractures and faults. Normal, parallel bedded sequences are often sandwiched between distorted units, suggesting that the material failed as a series of smaller slumps rather than as a single mass failure. Below the slump mass, two older fan lobes were penetrated. The entire sequence is composed of silts and silty clays with minor, localized sand units.

\section{PETROLOGY}

\section{Gravels}

Gravels were cored near the base of both middle fan channel sites (621 and 622). The gravels grade upward into sands containing thin mud interbeds. Clast-supported gravel occurs in a $60-\mathrm{cm}$ interval at the base of Site 621. This gravel is graded and devoid of fine-grained matrix, a condition that most likely results from liquefaction and loss of the sandy matrix during raising of the core barrel. Clasts are up to $3 \mathrm{~cm}$ long, rounded and subrounded, near-spherical, often faceted, and poorly sorted.

Petrographic study of oversized thin sections indicates that the gravels are composed primarily of chert and polycrystalline quartz (Fig. 5A, 5B). Accessory clast types include felsic and mafic igneous fragments (Fig. 5C), volcanic rock fragments (Fig. 5D), carbonate rock fragments, quartz-microcline intergrowths (Fig. 5E), quartz- and calcite-cemented sandstone and siltstone fragments, metamorphic rock fragments, and broken molluscan debris (Fig. 5F). Most chert consists of equant microcrystalline quartz (Fig. 5A). Inclusions of silt, clay, dolomite, organic matter, microfossils, and pyrite are common. Many chert clasts contain considerable microporosity as a result of leaching dolomite rhombs or other carbonate inclusions. The leaching is a product of subaerial weathering and is not due to diagenetic processes at the depositional site. Minor chert varieties are spherulitic chalcedony (Fig. 5G) and oolitic chert (Fig. 5H). Polycrystalline quartz types include stretched and schistose metamorphic, plutonic igneous, and vein varieties (Folk, 1980).

Pebbly muds and muddy gravels were also cored near the bottom of the two middle fan channel sites. They consist of rounded clasts set in a poorly sorted, silty clay matrix. These clasts are compositionally similar to the grain-supported gravels described above.

Composition of fan gravels is similar to Pleistocene upland gravels we have examined from south-central Louisiana. The nearest source for Mississippi Fan gravels is on the continental shelf near the head of Mississippi Canyon, indicating a minimum transport distance of over $220 \mathrm{~km}$ (Bouma and Coleman, 1984).

\section{Sands}

\section{Distribution}

Lower fan depositional lobes (Sites 614 and 615) contain the highest percentage of sand and coarse silt. Based on core and gamma-ray data, Site 615 has $65 \%$ net sand in the lower $274 \mathrm{~m}$ and $41 \%$ in the upper $202 \mathrm{~m}$; Site 614 contains $34 \%$ net sand. In contrast, middle fan overbank deposits (Sites 617 and 620) consist of 3\% sand, $25 \%$ silt, and $72 \%$ clay (Bouma and Coleman, 1984). Middle fan channel deposits, Sites 621 and 622, contain $16 \%$ and $23 \%$ net sand, respectively. The lower fan channel-levee complex (Site 623) has 12\% net sand, while the lower fan levee (Site 624 ) contains only $2 \%$ net sand. Beneath the "slump deposits" at Site 616, two older fan lobes were penetrated, of which the older lobe contains $7 \%$ net sand, whereas the younger lobe has $34 \%$ net sand (Bouma and Coleman, 1984).

\section{Texture}

Generally, sands range from very fine to very coarse, with most being fine and very fine grained, and moderately to well sorted (Fig. 6). A few sands display poor sorting. Coarse and very coarse sands often contain rounded granules and pebbles of chert and quartz.

Nearly all sands contain greater than $5 \%$ detrital matrix (all detrital grains $<30 \mu \mathrm{m}$ ) and thus are texturally immature. Medium and coarse sands, however, often contain less than $5 \%$ matrix and are submature or mature. Figure 7 shows the proportion of terrigenous grains, matrix, and detrital carbonate (calcareous silt and biogenic calcite). Inspection of that figure indicates that most Mississippi Fan sands contain minor carbonate and less than $15 \%$ detrital matrix. Fine and very fine sands contain the highest percentage of matrix and detrital carbonate.

Grain roundness varies directly with grain size. Fine and very fine sand grains are usually angular or subangular, whereas medium and coarse grained ones are subrounded to well rounded. Grain shape (sphericity) is quite variable. Most quartz and feldspar grains are subspherical, whereas many of the sedimentary, metamorphic, and volcanic rock fragments are disk-shaped or bladed. Surfaces of coarse and very coarse quartz grains are frequently polished. Embayments and corrosion pits on quartz grains, as described by Potter (1978), are very rare.

\section{Composition}

Mississippi Fan sands are quartzose, contain minor detrital matrix and biogenic carbonate, and variable amounts of woody organic debris. The ternary diagram shown in Figure 7 indicates that sand-sized terrigenous grains commonly form more than $80 \%$ of whole-rock volume, excluding porosity and woody fragments. The remainder is composed of detrital matrix and biogenic carbonate. Figure 8 shows that most sands are feldspathic litharenite, sublitharenite, or subarkose according to Folk's (1980) classification. A few sands are lithic arkose, with only one litharenite and arkose. Replotting all lithic sands on a sedimentary-volcanic-metamorphic rock fragment diagram (Fig. 9) shows that most are sedarenites (Folk, 1980). Modern Mississippi River sand is compositionally similar to fan sands, but contains a higher proportion of unstable rock fragments, chiefly metamorphics (Potter, 1978). This disparity may be related to selective sorting during transport into the deep Gulf of Mexico basin. The overall similarity in grain framework composition, however, indicates that fan sands were derived chiefly from a Mississippi River source. 

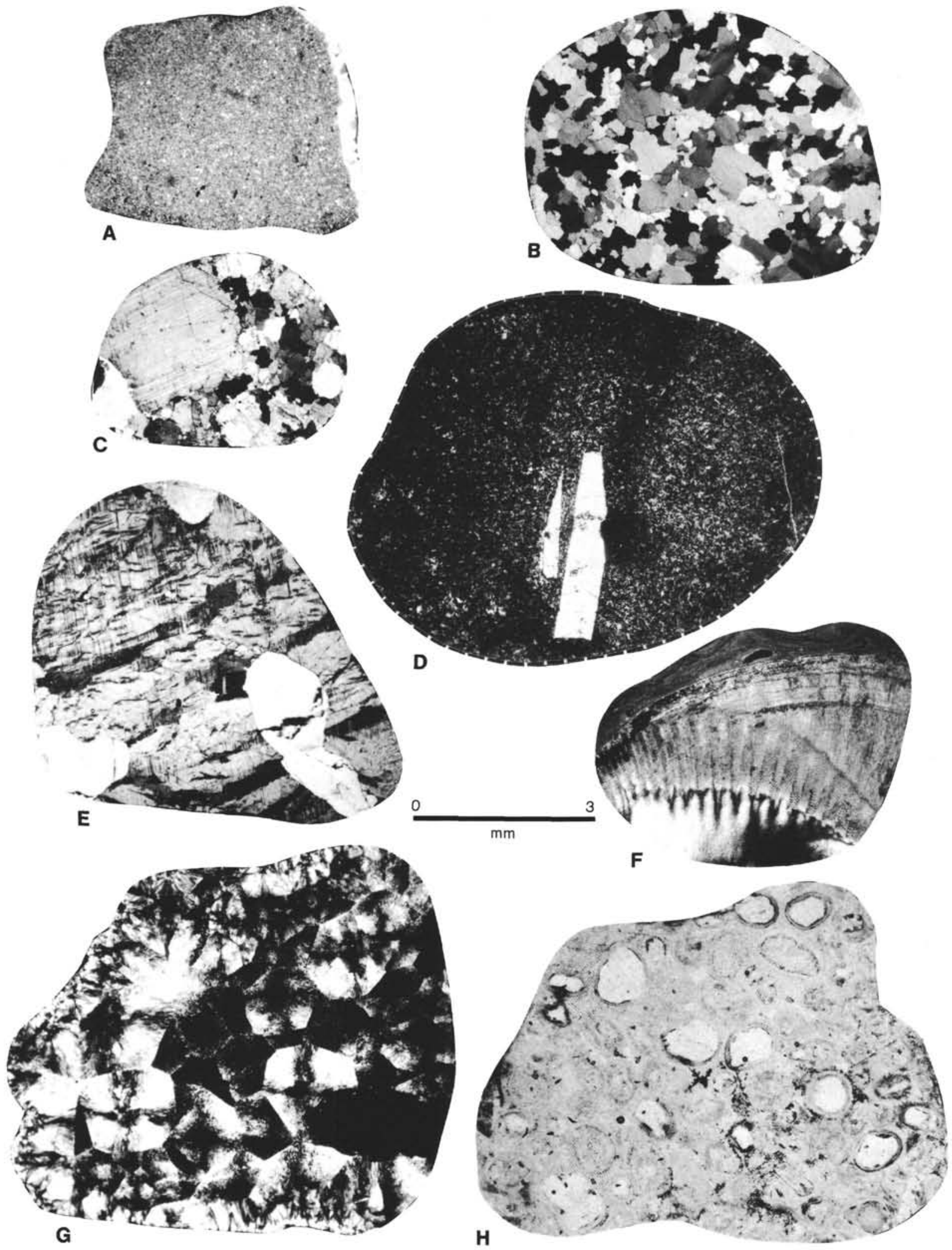

Figure 5. Composite figure of clast types in gravel at the base of the middle fan channel, Site 621 . Scale is the same for each photomicrograph. A. Rounded chert consisting mainly of equant microcrystalline quartz. Dark inclusions are pyrite. Crossed nicols. B. Rounded polycrystalline quartz composed of subequant crystals with crenulated boundaries. Crossed nicols. C. Rounded plutonic igneous rock fragment (granitic) composed of quartz, plagioclase, and potassium feldspar. Crossed nicols. D. Volcanic rock fragment consisting of large plagioclase phenocrysts in a turbid aphanitic groundmass. Plane polarized light. E. Well-rounded quartz-microcline intergrowth, probably derived from granitic or gneissic source area. Crossed nicols. F. Broken and rounded molluscan fragment of shallow-water origin. Crossed nicols. G. Rounded grain of spherulitic chalcedony. Crossed nicols. H. Oolitic chert containing silicified ooids with quartz centers. Plane polarized light. 


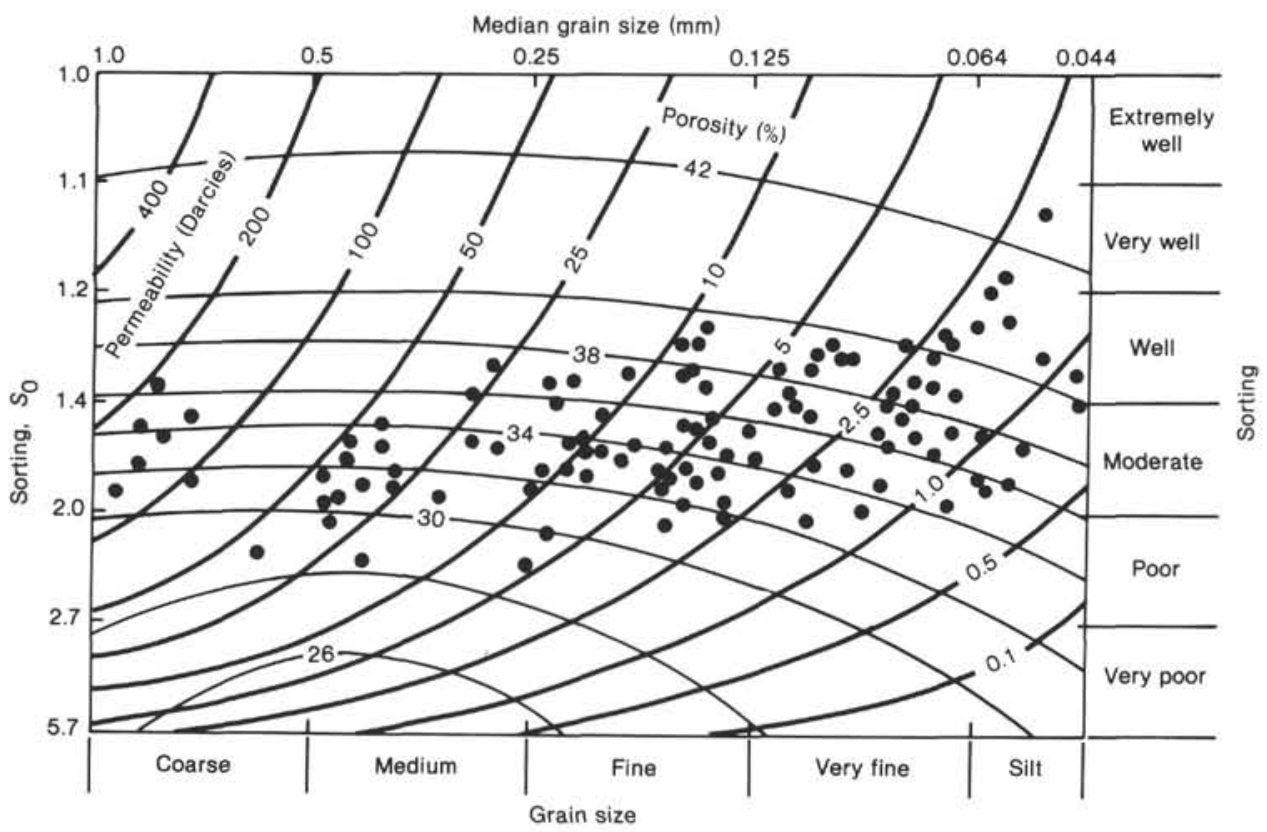

Figure 6. The relationship between size, sorting, porosity, and permeability of unconsolidated Mississippi Fan coarse silts and sands as determined from thin section (diagram courtesy of R. M. Sneider).

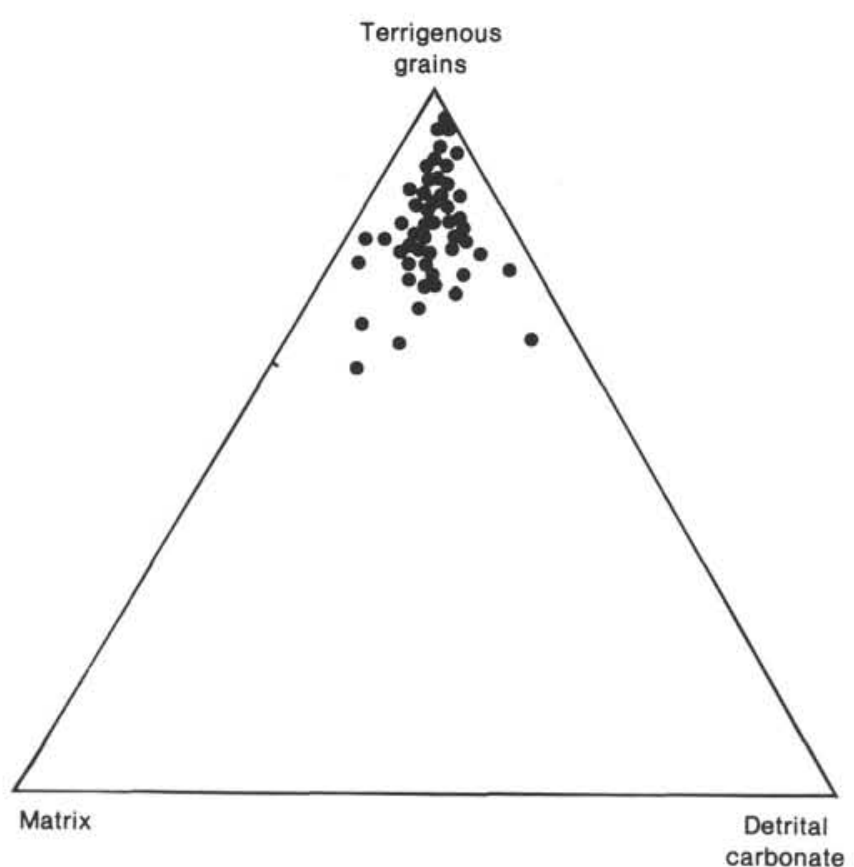

Figure 7. Ternary diagram of Mississippi Fan sands showing proportion of terrigenous grains, matrix, and detrital carbonate.

Matrix consists of terrigenous mud with subordinate silt-sized carbonate. The carbonate rarely forms more than $5 \%$ of total whole-rock volume, and is most abundant in fine and very fine sands. SEM study indicates that the carbonate consists of reworked, calcareous skeletal debris (mainly coccolith plates) along with detrital calcite silt of unknown origin. Matrix occurs typically as an interparticle pore fill; however, in some sands, especially medium- and coarse-grained ones, allogenic clays

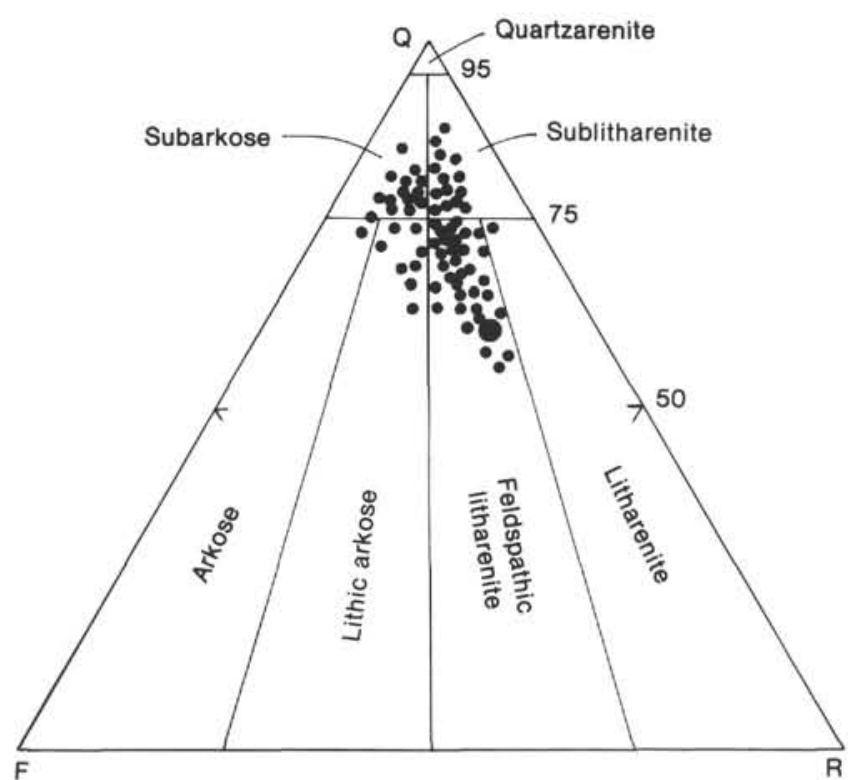

Figure 8. Framework composition of Mississippi Fan sands. The larger dot is the average composition of modern Mississippi River sand as determined by Potter (1978).

form grain coatings or bridges between framework grains (Fig 10). X-ray diffraction analysis of the $<2 \mu \mathrm{m}$ fraction of 23 representative sands indicates that kaolinite, chlorite, illite, and smectite occur in approximately equal amounts.

Quartz forms 55 to $90 \%$ of total grain framework (Fig. 8). The dominant variety is strained monocrystalline (Fig. 11) with subordinate polycrystalline types (Fig. 12). Unstrained monocrystalline quartz usually forms less than $1 \%$ of total grain framework. Monocrystalline grains sometimes display syntaxial quartz overgrowths that are 


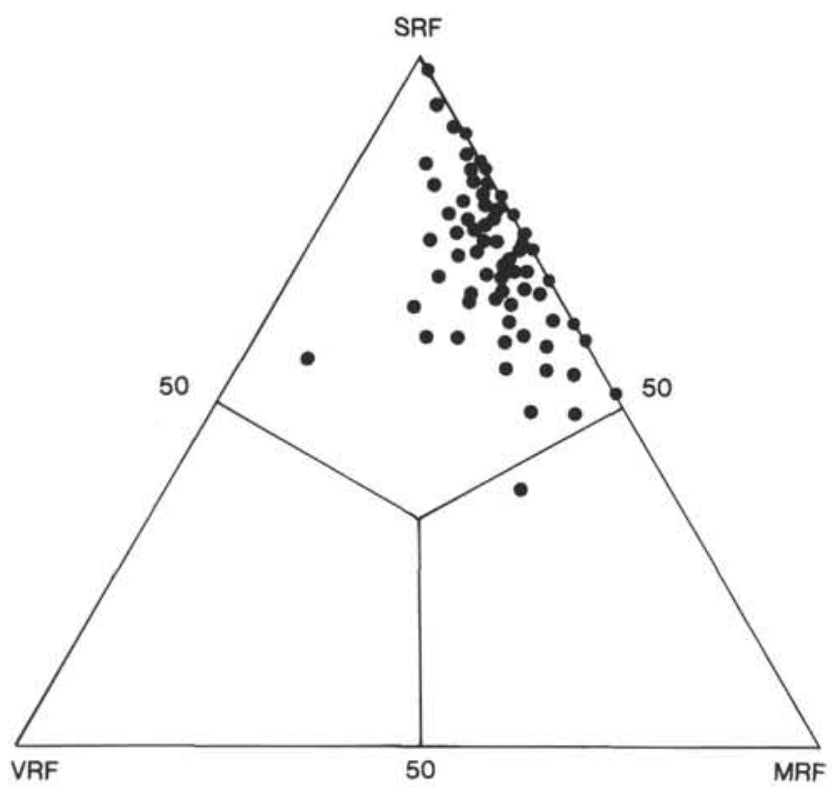

Figure 9. Ternary diagram showing proportion of sedimentary (SRF), volcanic (VRF), and metamorphic (MRF) rock fragments in Mississippi Fan lithic sands.

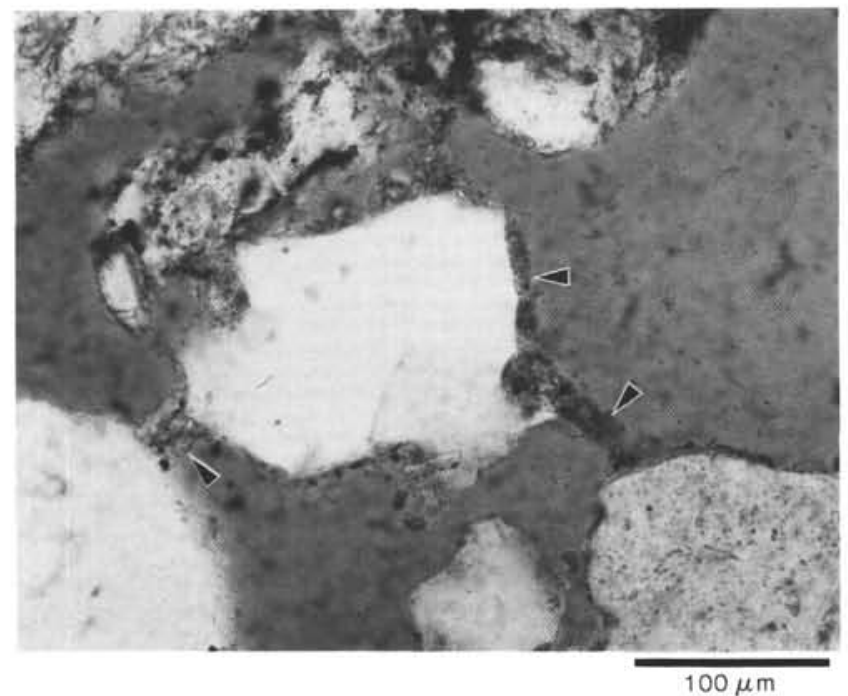

Figure 10. Thin section photomicrograph of medium-grained sublitharenite showing well-developed detrital clay coatings and bridges between framework grains (arrows). Medium gray areas are intergranular pore space. Plane polarized light. Sample 623-12-4, 30$60 \mathrm{~cm}$ (107.6 m sub-bottom).

abraded or rounded, which suggests derivation from an older sedimentary source. Polycrystalline quartz is most abundant in medium and coarse sands where it forms up to $25 \%$ of total quartz content. Chief polycrystalline varieties are stretched metamorphic and plutonic igneous, with minor vein and schistose metamorphic varieties.

Feldspar comprises 5 to $20 \%$ of framework grains (Fig. 8), and averages about $10 \%$. Plagioclase (Fig. 11) is the chief feldspar in fine and very fine sands, with subordinate orthoclase and microcline. However, in medium and coarse sands, microcline (Fig. 12) is usually

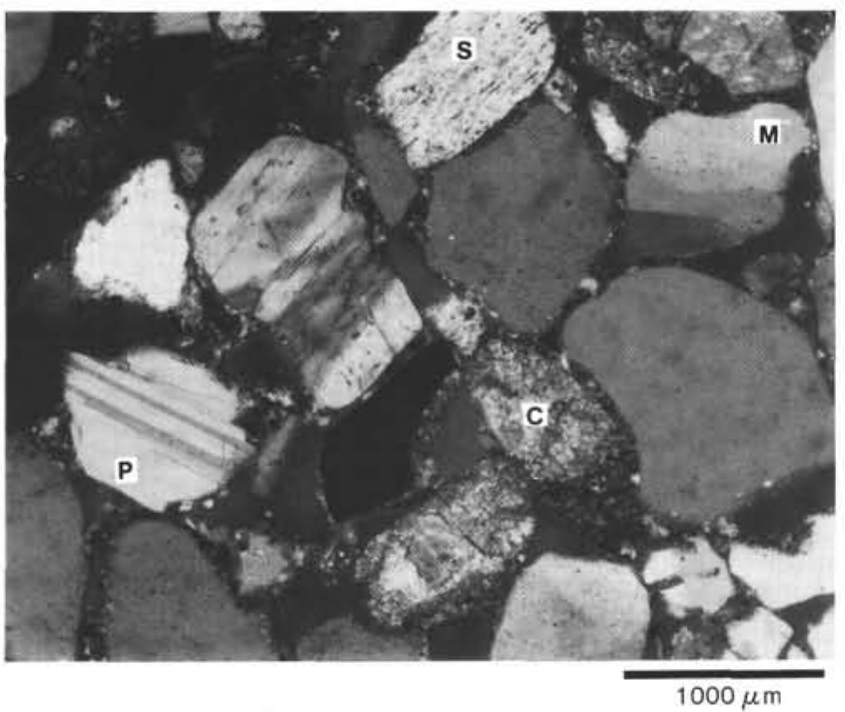

Figure 11. Photomicrograph of medium-grained sublitharenite. The sand consists of angular to subrounded grains of strained monocrystalline quartz $(\mathrm{M})$, plagioclase $(\mathrm{P})$, sericitized plagioclase $(\mathrm{S})$, and carbonate rock fragments $(C)$. Note clay coatings around grains. Dark gray areas between grains represent pore space. Partially crossed nicols. Sample 623-12-4, 30-60 cm (107.6 m sub-bottom).

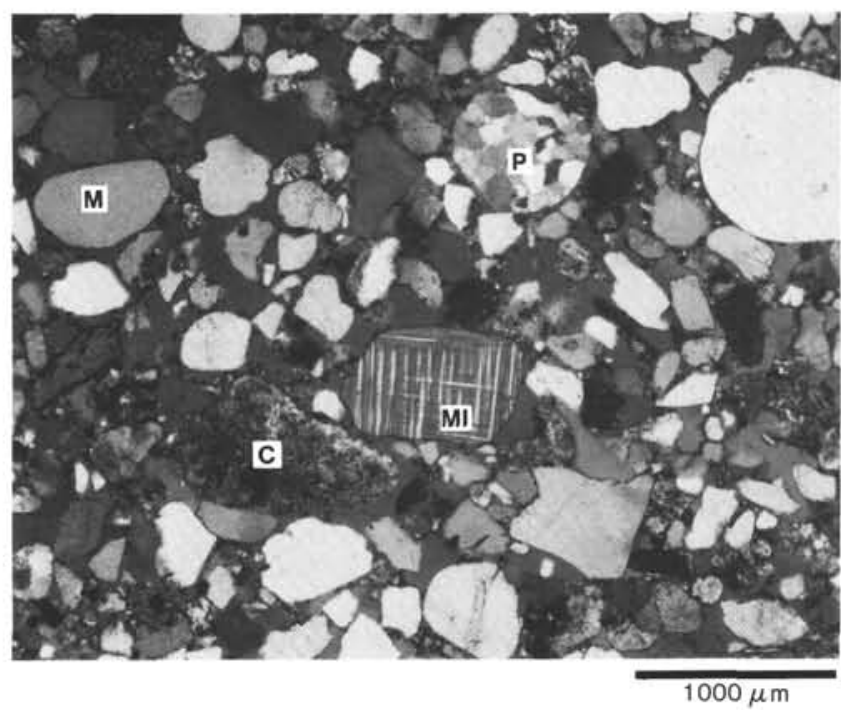

Figure 12. Photomicrograph of medium-grained sublitharenite. Note variability in rounding with larger grains being well rounded. Grain types include monocrystalline (M) and polycrystalline (P) quartz, microcline (MI), and chert (C). Partially crossed nicols. Samples $623-12-4,30-60 \mathrm{~cm}$ (107.6 m sub-bottom).

dominant. Minor euhedral plagioclase that displays oscillatory zoning indicates volcanic provenance. Rare intergrowths of plagioclase and rod-shaped quartz (myrmekite), and sodic plagioclase within host $\mathrm{K}$-feldspar (perthite) are found in some medium and coarse sands. Plagioclase often is partly altered to sericite (Fig. 11) and/or turbid clay minerals, and about $5 \%$ of the grains show evidence of dissolution. Leaching has generally followed cleavage planes and/or twin lamellae, but in some cases was restricted to grain cores, which presumably were calcium-rich. Microcline (Fig. 12) and orthoclase 
are fresh and show few dissolution effects. Feldspar dissolution most likely results from subaerial weathering in the source area or in transitory depositional sites prior to deposition in the deep Gulf basin.

Rock fragments form 5 to $35 \%$ of the grain framework (Fig. 8). Sedimentary rock fragments comprise more than $50 \%$ of the total rock fragment population (Fig. 9), with chert being dominant (Fig. 12). Many chert grains contain inclusions of rhombic dolomite, calcite, clay, and rare microfossils. The abundance of carbonate inclusions indicates a carbonate source terrane, probably Paleozoic carbonates in the Mississippi River drainage basin. Carbonate inclusions in some chert grains have been leached (Fig. 13) leaving a spongy, microporous mass (tripolitic chert). Leaching probably took place in the source area.

Mudstone rock fragments, mainly claystone and silty claystone (Fig. 14), are next in abundance to chert. Sandsized grains are rounded and well-rounded, whereas larger mud clasts commonly display angular morphologies (Fig. 4A). Many mudstone fragments show compactional bending or other evidence of deformation, which suggest they were soft at the time of deposition. The soft mud fragments may be rip-up clasts of intrabasinal origin, while indurated mudstones are more likely of extrabasinal origin.

Other sedimentary rock fragments include carbonates and cemented quartz sandstone and siltstone. Carbonate fragments are well-lithified micrites and sparites (Fig. 11) that are rounded and occasionally fossiliferous. The carbonates were probably derived from mid-continental Paleozoics. Rare quartz-rich sandstone and siltstone fragments are cemented by calcite, and may also have come from extrabasinal sources. However, microscopic examination of washed coarse fraction samples, as well as the occurrence of high-density clots on X-ray radiographs in sand units, especially thin graded sands (Fig. 2C), sug-

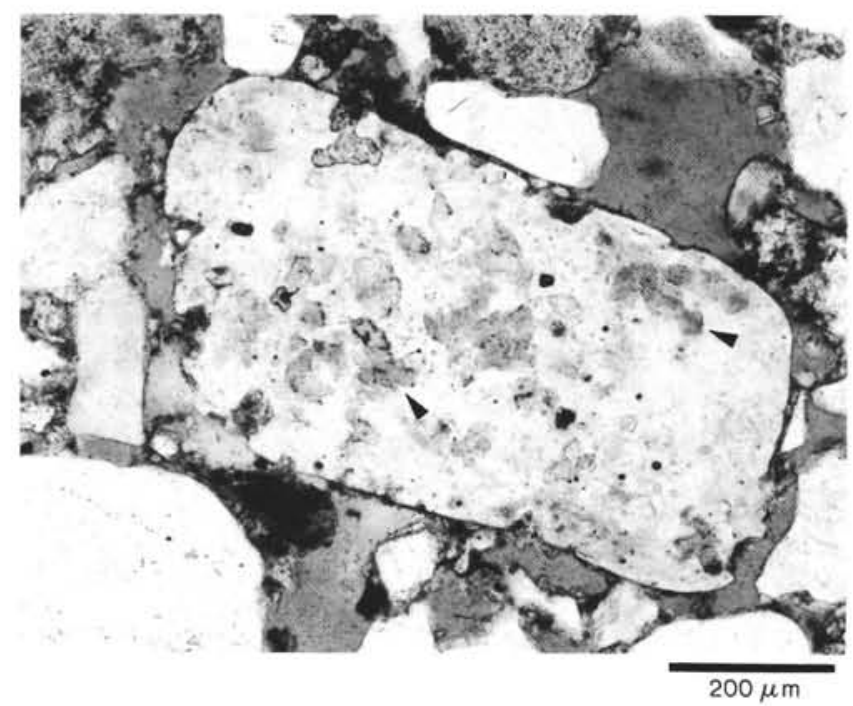

Figure 13. Thin section photomicrograph of medium-grained sublitharenite. Well-worn chert fragment (center) shows micropores (arrow) produced by leaching of carbonate inclusions; resultant grain has a spongy texture. Plane polarized light. Sample 621-33-2, 108$147 \mathrm{~cm}$ (213.8 m sub-bottom).

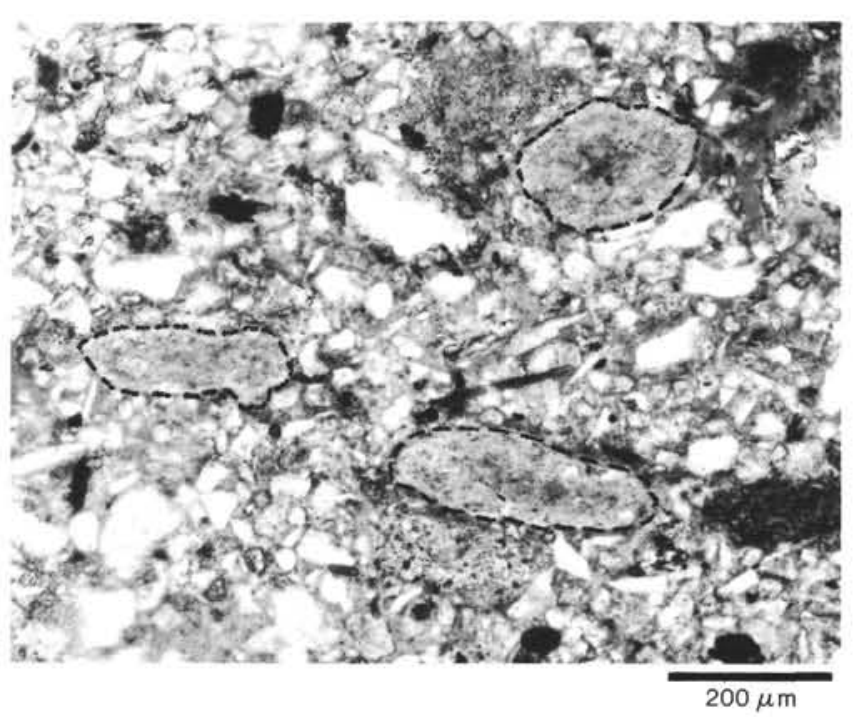

Figure 14. Photomicrograph of a silty, fine-grained, moderately sorted, feldspathic litharenite. Note elongate, well-rounded clay fragments. Partially crossed nicols. Sample 623-16-1, 90-92 cm (140.6 m sub-bottom).

gests that these grain types can also have an intrabasinal origin.

Subordinated rock fragments are metamorphics, volcanics, and minor plutonics. Combined, these varieties seldom form more than $30 \%$ of the total rock fragment population (Fig. 9). Metamorphic fragments are primarily schist and phyllite with minor gneiss. The nearest metamorphic source terranes are the southern Appalachians and Ozarks. Volcanic rock fragments consist usually of euhedral feldspar laths set in a turbid, aphanitic groundmass. These fragments are worn and rounded, and feldspars within are often partly leached. These grains were probably derived from an older volcanic terrane, perhaps Cretaceous volcanics in Arkansas. Rare volcanic grains contain feldspar laths in a light-brown, glassy groundmass. Glassy volcanic rock fragments are very fine sandor coarse silt-sized, and fresh and angular, which suggests direct volcanic derivation. Plutonic igneous fragments rarely constitute more than $5 \%$ of total rock fragments, and occur most frequently in medium and coarse sands. Felsic varieties, consisting of quartz-feldspar intergrowths, are dominant. Rare mafic types include diabase and basalt.

Accessory detrital constituents include mica, glauconite, dolomite, heavy and opaque minerals, woody fragments, and biogenic debris. Mica is most common in fine sands and silts. Muscovite is dominant with subordinate biotite and rare chlorite. Well-rounded glauconite grains are rare and restricted to fine and very fine sands; they are probably reworked from older Tertiary sediments.

Silt- to fine sand-sized dolomite that displays abrasion or rounding is interpreted to be detrital in origin. Hsü (1960) noted the frequent occurrence of reworked, detrital dolomite in heavy mineral separations from Gulf Coast beach sands sourced by Mississippi River drainage. The dolomite is probably derived from Paleozoic platform carbonates of the central stable region (Mur- 
ray, 1961). Minor detrital dolomite displays hollow cores (Fig. 15), which result from selective leaching of calcium-rich centers of zoned crystals. At present, we do not know whether leaching occurred in the source area or results from diagenetic processes operative in the temporary storage area on the shelf or in the shallow-subsurface fan environment. Much of the dolomite in coarse silts and fine sands is euhedral and shows no evidence of wear. Also, this dolomite type occurs in growth clusters between detrital grains, which suggests an authigenic origin.

Heavy minerals form less than $1 \%$ of whole-rock volume and are most common in coarse silts and very fine sands. Most grains are rounded or well rounded. Dominant types are amphibole, epidote, garnet, pyroxene, zircon, and tourmaline. Subordinate ones include apatite, kyanite, staurolite, monazite, sphene, and reddish-brown basaltic hornblende. Partial dissolution of a small percentage of amphibole, pyroxene, and garnet probably occurred prior to deposition on the fan. Detrital opaque grains are magnetite, ilmenite, leucoxcene, and pyrite. The abundant amphibole-epidote assemblage indicates that the Mississippi province was the major source area (Davies, 1972). The presence of a kyanite-staurolite assemblage, however, suggests that some sediment was derived from the Eastern Gulf province (van Andel and Poole, 1960). Rare basaltic hornblende may come from Rio Grande sources or be reworked from older Tertiary sediments that were partly sourced by the Rio Grande province (van Andel and Poole, 1960).

Woody organic fragments are found throughout the sands (Figs. 2A, 3B, and 16), but are most common in fine and very fine grained ones, as well as in medium and coarse silts. The organic particles range from fine silt to pebble size, and greatly resemble the detrital, organic "coffee-grounds" that are transported by the present Mississippi River during spring floods. Woody organic grains are typically black (inertite) in thin section

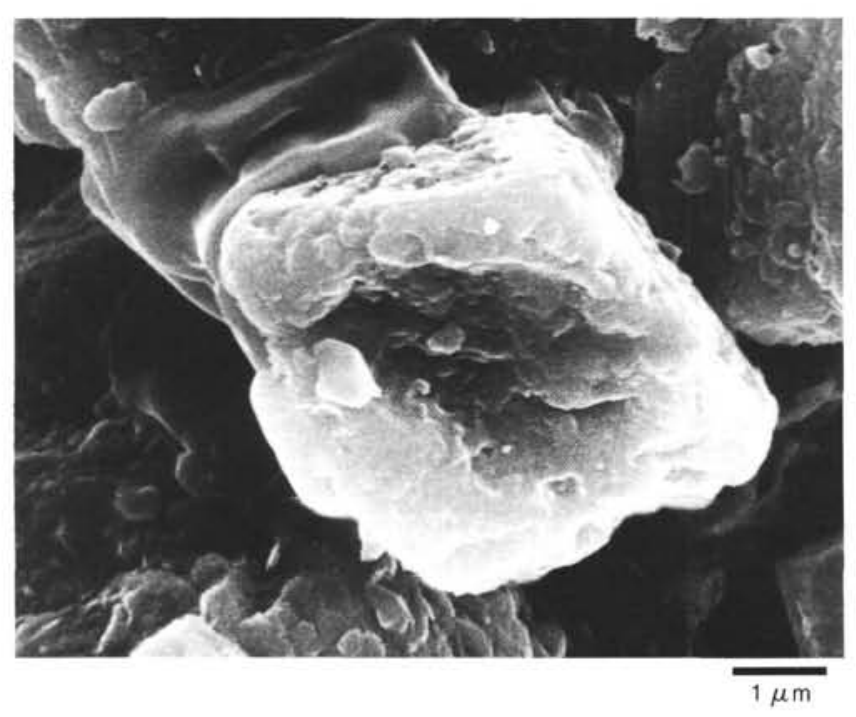

Figure 15. SEM micrograph of a leached dolomite rhomb. The hollow core probably results from selective dissolution of a calcium-rich grain center. Sample 616-3-5, 78-108 cm (23 m sub-bottom).
(Fig. 16), but in some cases display a golden brown color and cellular structure. Total organic carbon analyses of 13 representative sand samples from various depositional settings in the fan show values that range from 0.7 to $7.9 \%$ (mean $=2.6 \%$ ). Rock-Eval pyrolysis data for the same samples indicate that the hydrogen index was low (mean $=56$; range 41-79), and the oxygen index was high $($ mean $=212$; range 31-608). These data indicate that the detrital organics have low convertibility and are highly oxidized, and thus have limited potential as a hydrocarbon source. However, dessication shrinkage and diagenetic destruction of the organics after deeper burial may actually enhance porosity. Some of the oversized pores commonly seen in ancient sands may result from this process.

Other than woody grains, sand-sized biogenic components rarely form more than a small percentage of total grain framework. Broken and rounded skeletal debris, including echinoderm, mollusk, and foraminifer tests are the most common. Mollusk fragments are usually bored and have micrite rims, while foraminifer tests are often filled with calcite or pyrite. Sponge spicules, broken silicoflagellates, and reworked nasselarian radiolarians are rare components.

\section{Authigenic Constituents}

Authigenic minerals in the sands include dolomite, pyrite, clays, and traces of gypsum and calcite. As discussed previously, authigenic dolomite occurs as euhedral rhombs or clusters of rhombs. Authigenic clays, identified by EDX and crystal morphology in SEM, grew on a substrate of pore-bridging detrital clay (Fig. 17) as well as other grain surfaces. Trace amounts of smectite are the only authigenic clays identified in the sands. Pyrite most commonly occurs as framboids or clusters of framboids, and typically is associated with clay- or organicrich areas. Pyrite occurs also as a chamber-filling ce-

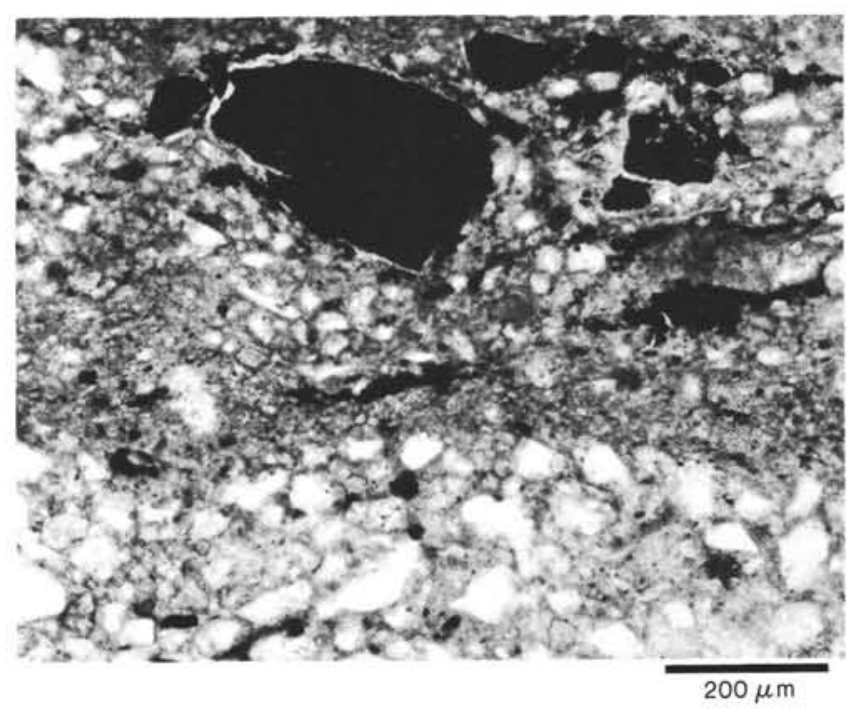

Figure 16. Thin section photomicrograph of graded, very fine sand containing fine to coarse particles of wood. Subangular clayey sand at base grades upward into organic-rich clayey silt. Plane polarized light. Sample $615-47-1,47-77 \mathrm{~cm}$ (448 m sub-bottom). 


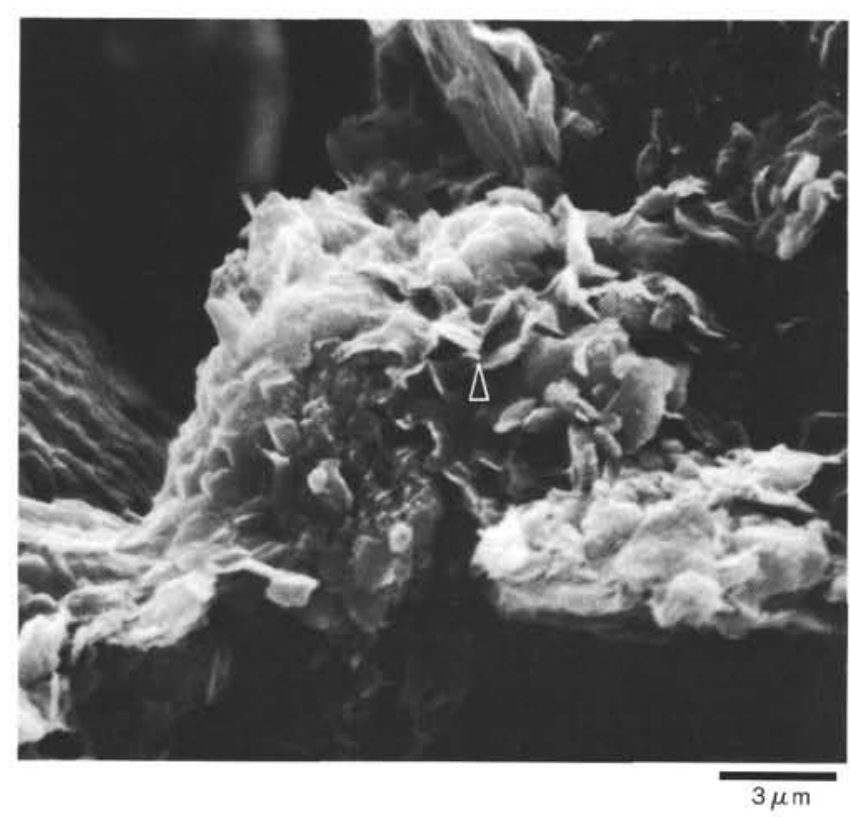

Figure 17. SEM micrograph of authigenic smectite (arrow) growing on detrital pore-bridging clay in a fine sand. Sample 615-3-4, 83$85 \mathrm{~cm}$ (17.4 m sub-bottom).

ment in foraminifers. Authigenic gypsum, a rare constituent in the sands, forms large poikilotopic crystals (Fig. 18) that engulf surrounding terrigenous grains. Calcite cement occurs in trace amounts in a few very fine sands.

\section{Porosity}

Two techniques were used to determine porosity of Mississippi Fan sands. Where samples were interpreted as undisturbed by the coring or sample preparation process (i.e., retained internal fabric, contained pore-lining

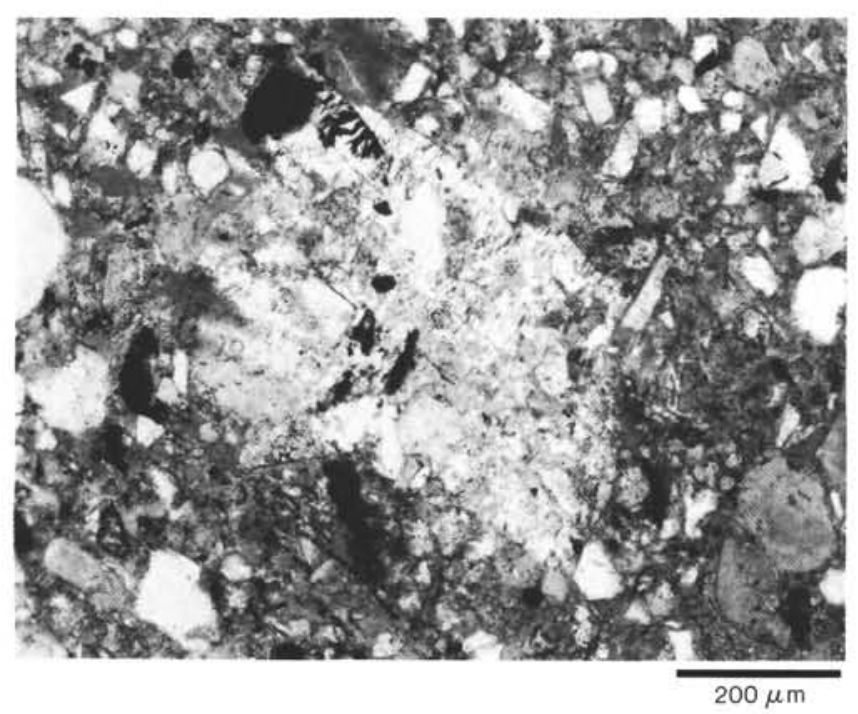

Figure 18. Thin section photomicrograph of large, poikilotopic gypsum (center) of authigenic origin. The gypsum has engulfed quartz and other terrigenous grains as well as woody organic debris (black areas within gypsum). Partially crossed nicols. Sample 623-16-2, $100-102 \mathrm{~cm}$ (142.6 m sub-bottom). or pore-bridging clay, etc.), volume percent porosity was determined by point counting. Of 50 undisturbed sand samples, porosity values ranged from 5 to $35 \%$, with most in the 20 to $30 \%$ range.

If sands showed evidence of disruption, porosity was estimated using size and sorting characteristics (Beard and Weyl, 1973). Figure 6 shows the relationship between mean size, sorting, and porosity and permeability of Mississippi Fan sands. The figure illustrates that most porosities fall within the 30 to $40 \%$ range, which is probably a more reasonable estimate of true porosity values. Porosity values derived from thin-section analyses are typically lower than those measured by other standard methods (Halley, 1978). Permeabilities estimated from size and sorting usually range between 1 and 25 Darcies, although some coarse sands are estimated to have values as high as 200 Darcies (Fig. 6).

More than $90 \%$ of the porosity in these sands is primary intergranular, located between framework grains (Fig. 11). Remaining pore types include micropores $(<0.5$ $\mu \mathrm{m})$, grain dissolution pores, and intraskeletal pores in foraminifer tests and other skeletal fragments. Most microporosity is located within allogenic and authigenic clays; subordinate microporosity occurs in argillaceous rock fragments, tripolitic chert fragments, volcanic rock fragments, skeletal debris, woody organic fragments, and micro-sized grain dissolution pores. As noted earlier, minor grain dissolution pores (micro- and macro-sized) result from leaching of feldspars (mainly plagioclase), volcanic rock fragments, dolomite, chert, unstable heavy minerals, carbonate rock fragments, skeletal debris, and other labile grains. Most leaching is interpreted to have occurred under subaerial conditions, prior to deposition on the fan.

\section{Silts and Clays}

\section{General}

Fine-grained sediments of the Mississippi Fan are concentrated in the middle fan passive channel fill and in overbank deposits of both the middle and lower fan. These sediments are composed of clays, silty clays, and silts and are characterized by a variety of sedimentary structures, the most common of which is graded bedding of varying thickness.

Aside from sediment deformational structures that are common in overbank deposits of the middle fan, the most common structures of the overbank facies in both the upper and lower fan are graded parallel laminations. Commonly, the silts and silty clays that comprise these laminations are rich in woody organic fragments. In thin section the organic remains are bedded (Fig. 19). One of the characteristic features of these fine-grained deposits is the thin nature of most graded units (Fig. 3A). Lower fan overbank deposits as well as fine-grained interbeds of the channel-mouth sheet sands may have up to 15 to 20 micrograded units per centimeter. In addition to these features, small clay clasts, stranded ripples, a few microcross-laminated silts, and small load features have been observed. Bioturbation is rare. Burrowing usually occurs at the clay-rich tops of graded units. 


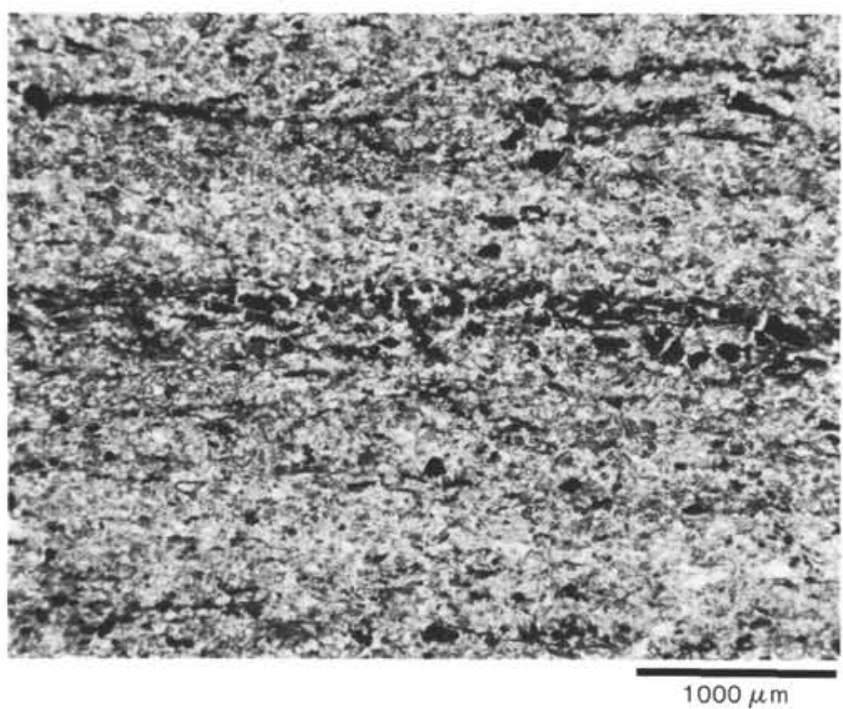

Figure 19. Photomicrograph of bedded organic particles in silt. Plane polarized light. Sample $622-15-5,58.5-60.5 \mathrm{~cm}$ (129.9 m sub-bottom).

The clay-rich passive channel fills of the middle fan contain repetitive occurrences of poorly defined graded units composed of silty clay to clay and silt to clay sediments. Loading in these fine-grained sequences has caused minor deformation, primarily in the form of fractures and small offsets of laminae.

\section{Composition}

X-ray diffraction analyses of muds (silt, silty clay, and clay) from all major depositional environments on the fan as well as two intraslope basins (Sites 618 and 619) suggest considerable variability in relative percentages of smectite, illite, and kaolinite. The dominant clay mineral is smectite, with subordinate illite and kaolinite. Relative percentages between these clay mineral species are similar to those found on the modern Mississippi River delta front and the upper continental slope (Roberts, 1985). At this early stage of investigation, it is premature to characterize significant variations within and between depositional environments. However, we are confident that a significant difference exists between the average clay mineral signature of the intraslope basins (Sites 618 and 619) as compared to that of the Mississippi Fan (Fig. 20). Intraslope basin sediments display increases in illite and kaolinite at the expense of smectite compared to the average clay mineral composition of the fan. As suggested for similar variations between shelf and undisturbed slope sediments opposite the modern Mississippi Delta (Roberts, 1985), this trend toward increased kaolinite and illite probably indicates the important influence of a pelagic clay component. Fan clays are compositionally closer to those currently being deposited by the Mississippi River.

Petrographic study of a large number of silts and silty clays indicates that angular quartz is the dominant terrigenous component (Fig. 21). Accessory terrigenous grains include orthoclase, plagioclase, muscovite, biotite, mudstone rock fragments, and opaque and heavy minerals (Fig. 21). The heavy mineral suite is similar to

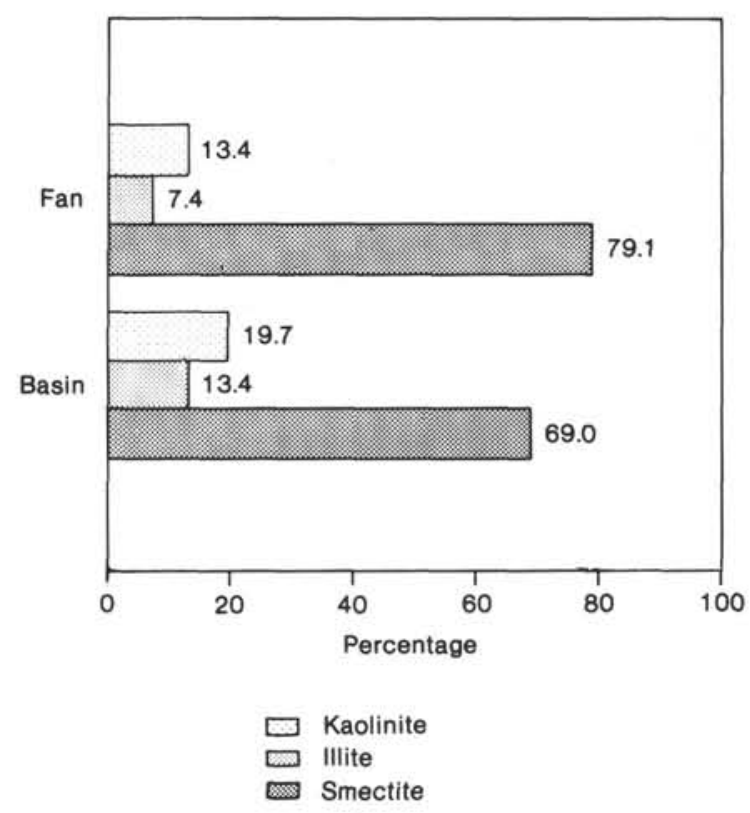

Figure 20. Bar graph of average clay mineral content of Mississippi Fan sediments as contrasted with intraslope sediments (Sites 618, 619). Data are based on peak areas derived from 112 XRD analyses ( 88 from Mississippi Fan; 24 from intraslope basins).

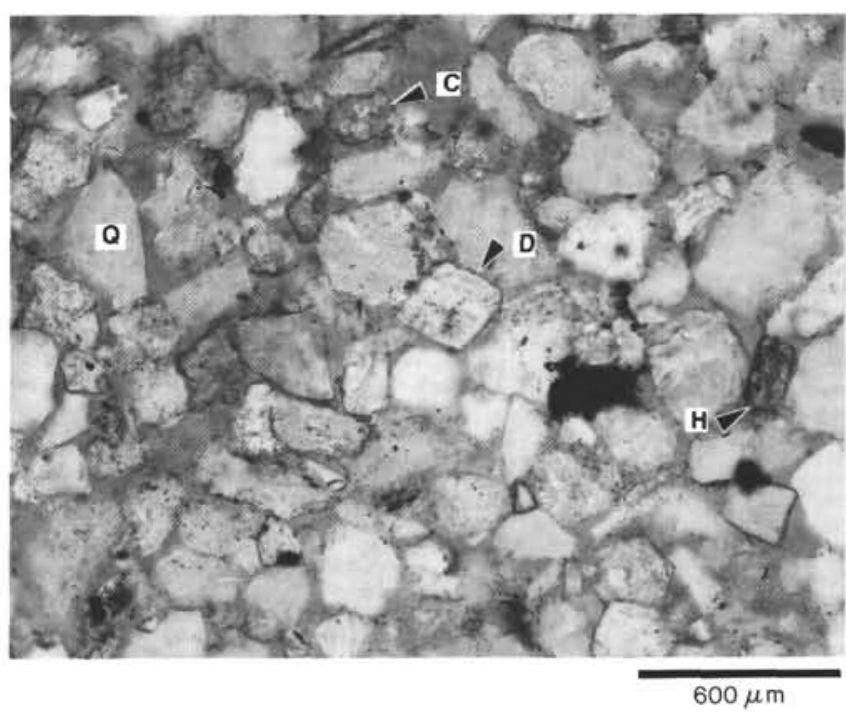

Figure 21. Thin section photomicrograph of coarse silt composed of angular quartz $(\mathrm{Q})$, carbonate debris $(\mathrm{C})$, heavy minerals $(\mathrm{H})$, and dolomite (D). Partially crossed nicols. Sample 616-18-1, 61-91 cm (163 $\mathrm{m}$ sub-bottom).

that of the sands. Woody organic debris is very common in medium and coarse silts, where it may form up to 20 percent (by volume) of the sample. Usually, the organics occur in discrete layers (Fig. 19); less commonly they are disseminated evenly throughout the sample. Biogenic components are more common in muds than sands; most are silt-sized calcareous fragments of uncertain origin. These fragments often form 10 to $20 \%$ of total sample volume. Preliminary SEM work suggests that much of the fragmented calcareous debris seen in thin section is actually a mixture of allogenic clay, fine broken skeletal debris, and coccolith plates. Rare biogenic components 
in muds are benthic and planktonic foraminifers, nasselarian radiolarians, sponge spicules, and broken silicoflagellates. Glauconite, probably of reworked origin, is a rare component in coarse silts. Silt-sized detrital dolomite rhombs, as described previously, form up to $3 \%$ of some silts (Fig. 21).

SEM examination of mud samples indicates that most clay is allogenic. In silts the clay occurs mainly as interparticle pore fills, although some form coats about framework grains. Authigenic smectite is relatively common in coarse and medium silts, but has not yet been identified in clays or silty clays we have examined.

Although only small amounts of gypsum have been found as an authigenic constituent in sands, much more of this mineral is present in the silt and clay fractions (Fig. 22). Both thin-section and SEM examination of silts and clays indicates that gypsum occurs as single crystals or clusters of crystals that penetrate surrounding finegrained, clay-rich sediment. In clay-poor silts, the gypsum occurs as poikilotopic crystals that engulf adjacent framework grains. Individual gypsum crystals are up to $1.5 \mathrm{~mm}$ long, although most range between 0.4 and $0.8 \mathrm{~mm}$.

Other common authigenic minerals in the silt and clay fraction are calcite, dolomite, and pyrite. These authigenic phases form less than $1 \%$ of the total sediment. Calcite occurs in several forms, including cemented silt grain clusters (Fig. 1C), cavity fills in foraminifer tests, and precipitates on grain surfaces. Euhedral dolomite rhombs, which show no evidence of wear (Fig. 23) or form crystal aggregates, are interpreted as authigenic. These dolomite rhombs are most common in medium and coarse silts. Pyrite occurs as framboids or clusters of framboids and also fills foraminifer tests. Framboidal pyrite is most common in clays and silty clays, where it is associated with organic matter.

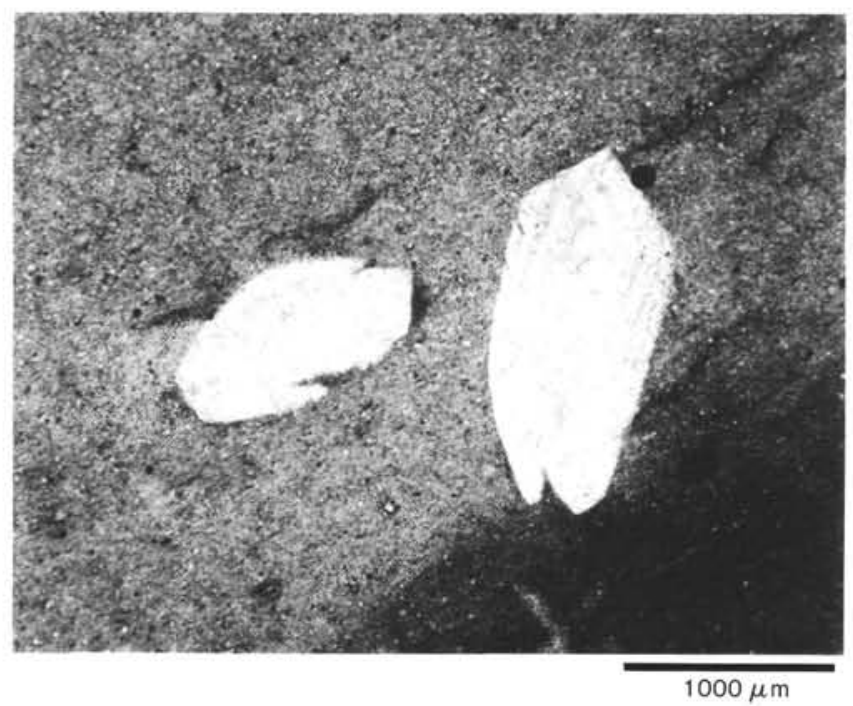

Figure 22. Thin section photomicrograph of two authigenic gypsum crystals in clay matrix. Plane polarized light. Sample 616-10-1, 77$79 \mathrm{~cm}(83.4 \mathrm{~m}$ sub-bottom).

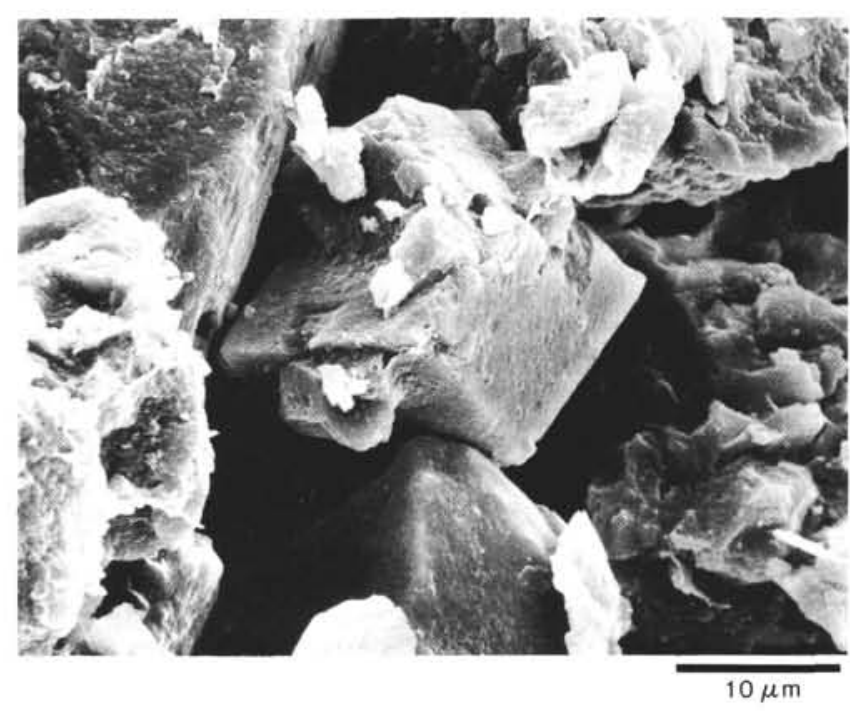

Figure 23. SEM micrograph of composite dolomite grain interpreted as authigenic. Sample $623-14-1,98-128 \mathrm{~cm}$ (122.5 m sub-bottom).

\section{CONCLUSIONS}

Initial sedimentologic and petrographic study of DSDP Leg 96 sediments yields the following conclusions:

1. Sands are concentrated in middle and lower fan channel fills as well as lower fan depositional lobes. Silts and clays occur as overbank deposits, passive channel fills, and interbeds associated with coarser facies. Graded bedding of varying thickness is the most common sedimentary structure in all environments.

2. Granule and pebble gravels occur at the base of middle fan channel fills. Gravels are composed of wellrounded chert and polycrystalline quartz, with minor metamorphic, sedimentary, and igneous rock fragments.

3. Sands are texturally immature, moderately to well sorted, and dominantly fine- and very fine-grained. Compositionally, most are feldspathic litharenite, sublitharenite, and subarkose. Sands commonly have thin-section porosities between 20 and $35 \%$ and woody organic contents from 0.7 to $7.9 \%$ total organic carbon.

4. Authigenic minerals occur in both sands and muds, but are most common in silts and clays. Smectite, dolomite, calcite, pyrite, and gypsum are the most common authigenic phases.

5. At this stage in their depositional history, the sands are clean, have high porosities, show only minor pore-reducing diagenetic effects, and thus have excellent hydrocarbon reservoir potential.

6. Petrology of Mississippi Fan cores suggests that it would be very difficult to determine a deep-water setting of these or similar deposits if we were working only with small samples such as sidewall cores or cuttings.

\section{ACKNOWLEDGMENTS}

Dr. Robert K. Olson of Amoco Research Center provided organic carbon and Rock-Eval pyrolysis data on selected sand samples. Dr. Syed Ali of Chevron did SEM work on a few of our samples and reviewed the manuscript. Amoco Production Company, New Orleans Region, sup- 
plied thin sections, SEM and EDX analyses, computer time, and some drafting as well as photographic support. William Dorsey of Amoco performed most of the SEM work. Celia Harrod helped with drafting, and Kerry Lyle did photographic work.

\section{REFERENCES}

Beard, D. C., and Weyl, P. K., 1973. Influence of texture on porosity and permeability of unconsolidated sand. Am. Assoc. Pet. Geol. Bull., 57:349-369.

Bouma, A. H., and Coleman, J. M., 1984. Seismic stratigraphy and sedimentology of Leg 96 drilling on the Mississippi Fan. Characteristics of Gulf Basin Deep-Water Sediments and Their Exploration Potential: Austin, Texas (Fifth Annual Research Conference, Gulf Coast Sec.), Soc. Econ. Paleontol. Mineral. Found., pp. 11-22.

Davies, D. K., 1972. Deep sea sediments and their sedimentation, Gulf of Mexico. Am. Assoc. Pet. Geol. Bull., 56:2212-2239.

Folk, R. L., 1980. Petrology of Sedimentary Rocks: Austin, Texas (Hemphill Publ. Co.).

Halley, R. B., 1978. Estimating pore and cement volumes in thin section. J. Sediment. Petrol., 48:642-650.

Harrell, J. A., and Eriksson, K. A., 1979. Empirical conversion equations for thin-section and sieve derived size distribution parameters. J. Sediment. Petrol., 49:273-280.
Hsü, K. J., 1960. Texture and mineralogy of the Recent sands of the Gulf Coast. J. Sediment. Petrol., 30:380-403.

Hunt, J. M., 1979. Petroleum Geochemistry and Geology: San Francisco (W. H. Freeman).

Murray, G. E., 1961. Geology of the Atlantic and Gulf Coastal Province of North America: New York (Harper).

Potter, P. E., 1978. Petrology and composition of modern big river sands. J. Geol., 86:423-449.

Roberts, H. H., 1985. Clay mineralogy of contrasting mudflow and distal shelf deposits on the Mississippi River delta front. Geo-Mar. Lett., 5:185-191.

van Andel, T. H., and Poole, D. M., 1960. Sources of Recent sediments in the northern Gulf of Mexico. J. Sediment. Petrol., 30: 91-122.

Walker, J. R., and Massingill, J. V., 1970. Slump features on the Mississippi fan, northeastern Gulf of Mexico. Geol. Soc. Am. Bull., 81:3101-3108.

Wilson, M. D., and Pittman, E. D., 1977. Authigenic clays in sandstones: recognition and influence on reservoir properties and paleoenvironmental analysis. J. Sediment. Petrol., 47:3-31.

Date of Initial Receipt: 26 April 1985

Date of Acceptance: 27 August 1985 